\title{
Ethylene degreening treatment of 'Ponkan' tangerine in the north of the Minas Gerais State, Brazil
}

\author{
Marcio Gama dos Santos da Costa' Luiz Carlos Chamhum Salomão "*, \\ Dalmo Lopes de Siqueira', Paulo Roberto Cecon', César Fernandes Aquino², \\ Leila Cristina Rosa de Lins', Robson Ribeiro Alves ${ }^{1 *}$
}

\begin{abstract}
The objective of the study was to elucidate the best combination of ethylene dose and exposure time aiming the degreening of 'Ponkan' tangerines. Fruits harvested with fully green peel were placed in airtight boxes, exposed during 24,48 and $96 \mathrm{~h}$ to ethylene gas at concentrations of 0 , $5,10,20$ and $40 \mu \mathrm{L} \mathrm{L-1}$, at a temperature of $20 \pm 1^{\circ} \mathrm{C}$ and $90 \pm 5 \%$ of relative humidity. On every $24 \mathrm{~h}$ the fruits were evaluated for color, Hue angle, total chlorophyll and carotenoids in the peel, solutes leakage, soluble solids, titrable acidity, $\mathrm{CO}_{2}$ production and fresh fruit weight loss. The degreening was more pronounced in fruits exposed to ethylene for $96 \mathrm{~h}$, independently the concentration. The electrolytes leakage peel increased linearly in fruit-control and those exposed to ethylene for $24 \mathrm{~h}$. In fruits treated for 48 and $96 \mathrm{~h}$, electrolyte leakage was observed only during ethylene exposure. The accumulated fresh mass loss did not exceeded $1 \%$ in the fruits. The ethylene dose did not affected the fruit respiratory behavior. The best combination aiming fruit degreening was the exposure during $96 \mathrm{~h}$ with $5 \mu \mathrm{L} \mathrm{L}^{-1}$ of ethylene, followed by 48 to 72 hours of storage after treatment.
\end{abstract}

Keywords: carotenoids, Citrus reticulata, chlorophyll, fruit peel color.

\section{Introduction}

The 'Ponkan' tangerine (Citrus reticulata,

Blanco) is one of the main citrus species produced in Brazil, with great consumer acceptance due to its sweet taste, easy peeling and expressive size when compared to other tangerines found in the market (Vale et al., 2006). However, under tropical conditions, the flesh of citrus fruits reaches physiological maturity, becoming edible before the peel color change, which cannot reach the orange color (Rodrigo \& Zacarias, 2007). This is due to the absence of low temperatures during fruit ripening, which are associated with the chlorophyll degradation process, and the synthesis and/or manifestation of carotenoids in the peel (Rodrigo \& Zacarias, 2007; Jomori et al. 2014), and may be an obstacle during fruit commercialization, since consumers associate the peel color with fruit maturity (Spósito et al., 2006).

An alternative is the peel degreening aiming the appropriate coloration for consumers, with the exogenous application of ethylene. The ethylene response in citrus occurs on the peel coloration, with a fast change from green to yellow or orange. The efficacy of the ethylene application on citrus greening depends on intrinsic factors to the process, such as ethylene concentration, exposure time, temperature, relative humidity and the fruit maturation stage 
(Matsumoto et al., 2009; Sdiri et al., 2012).

Matsumoto et al. (2009) concluded that the effect of ethylene on the accumulation of carotenoids in the peelvaries with the fruitexposure temperature, and the storage at $20^{\circ} \mathrm{C}$ promoted better results; However, under temperatures of 5 and $30^{\circ} \mathrm{C}$, there is a slow increase in carotenoid content in peel. Information on the leakage of solutes in the peel of citrus fruits after exposure to ethylene is scarce in the literature. For the juice characteristics, such as acidity, soluble solids and ratio, no significant changes are observed with the ethylene use in postharvest (Tietel et al., 2010; Mayuoni et al., 2011). This situation demonstrates the potential for the use of ethylene in Ponver's degreening, especially in regions such as the North of the Minas Gerais State, with high average temperatures throughout the year.

In traditional countries of citrus production for 'in natura' consumption and to export, the degreening has been applied to improve the fruit external appearance, mainly in tangerines and oranges, providing the development of the typical color of the variety, grown in nonfavorable conditions for color evolution (Rodrigo \& Zacarias, 2007; Matsumoto et al., 2009, Zhou et al., 2010, Mayuoni et al., 2011, Moscoso-Ramírez \& Palou, 2014).

Thus, the objective was to study the best combination of dose and time of ethylene exposure for the degreening of 'Ponkan' tangerines from the North of the Minas Gerais State, Brazil.

\section{Material and Methods}

Physiologically mature 'Ponkan' tangerine fruits were harvested in a commercial orchard in Matias Cardoso municipality, (14 $51^{\circ} 18^{\prime \prime} L S$ and 435'19" LO), Northern of Minas Gerais State. The region presents high daily average temperatures throughout the year, with low thermal amplitude and poorly distributed rainfall. During the $2007 / 2008$ crop year, in which the fruits developed, the minimum, average and maximum monthly temperatures were $18.3^{\circ} \mathrm{C}$, $25.6^{\circ} \mathrm{C}$ and $32.7^{\circ} \mathrm{C}$, respectively.

The fruits harvested were uniformly green in color, with average values of juice content, soluble solids and ratio (SS/AT) of $50 \% \mathrm{w} / \mathrm{w}, 9.0$
'Brix and 9.7, respectively. After harvest, fruits were packed in plastic boxes and covered with bubble wrap and transported to the Laboratory of Fruit Analysis of the Federal University of Viçosa, Brazil. In the laboratory the fruits were selected, classified and standardized for uniformity of the green color, size and absence of mechanical injuries or fungal infections. Subsequently, they were washed in running water and immersed during $5 \mathrm{~min}$ in Prochloraz (0.49 $\left.\mathrm{g} \mathrm{L}^{-1}\right)$ fungicidal solution and dried at room temperature.

About 45 hours after harvest, fruits were separated into groups of three, arranged in nylon nets, and packed in $186 \mathrm{~L}$ hermetic plastic boxes equipped with fans to promote air circulation and the homogeneous distribution of the applied ethylene. The boxes were placed in a refrigerated chamber with a temperature of $20 \pm 1^{\circ} \mathrm{C}$ and relative humidity of $90 \pm 5 \% .99 .9 \%$ ( $v$ ( v); the ethylene P.A. was used. The application was performed with graduated syringes, injecting the gas in the boxes through a silicone septa, located near the ventilation point, at the doses of $0,5,10,20$ and $40 \mu \mathrm{L} \mathrm{L}^{-1}$, and exposition times of 24,48 and $96 \mathrm{~h}$.

On every 24 hours, the boxes were opened to renew their internal atmosphere during $30 \mathrm{~min}$, being closed again, with re-application of ethylene, until treatment completion. After each time of ethylene exposure, fruits were placed in refrigerated chambers with similar temperature and relative humidity than during the treatment phase $\left(20 \pm 1^{\circ} \mathrm{C}\right.$ and $90 \pm 5 \%$, respectively). In the periods of $0,24,48,72$ and $96 \mathrm{~h}$ after the ethylene treatment, fruit samples were evaluated. The control fruits were kept for $24 \mathrm{~h}$ in a hermetic box and then carried to the same chamber than the other fruits, being sampled and evaluated on every $24 \mathrm{~h}$.

The experiment was set up in a subdivided plots scheme, with plots consisting of ethylene doses $\left(0,5,10,20\right.$ and $\left.40 \mu \mathrm{L} \mathrm{L}^{-1}\right)$ and evaluation times as subplots $10,24,48,72$ and $96 \mathrm{~h})$, in a completely randomized experimental design, with four replicates and three fruits per experimental unit.

Fruit color was measured in two diametrically opposite points in the equatorial zone of each fruit, using a Konica - Minolta 
colorimeter, model $C R-10$, for the $L^{*}, a^{*}, b^{*}, C^{*}$ and $h^{\circ}$ measurements. From these values, the Total Color Difference (CD) was determined, according to Mendoza et al. (2006). ED was determined by the total color difference between the values recorded in the fruits at each time of evaluation and those obtained for newly harvested fruits.

The pigments were extracted from peel discs of fruits with known area. The samples were crushed with the aid of fine sand and acetone PA. The ketonic extract was filtered using paperand with successive additions of acetone for complete removal of the pigments, being the volume filled to $25 \mathrm{~mL}$ with the same extractor. The absorbances were readed at the $470,644.8$ and $661.6 \mathrm{~nm}$ wavelengths, and the total chlorophyll and total carotenoid contents were estimated, according to Lichtenthaler (1987), with the results expressed in $\mu \mathrm{g} \mathrm{cm}^{-2}$ of sampled peel.

Soluble solids content (SS) was determined with the aid of a portable refractometer (Atago model $\mathrm{N} 1$-with range from 0 to 32 Brix), in samples composed of juices from three fruits of each experimental unit. The titratable acidity (TA) was obtained in a $5 \mathrm{~mL}$ aliquot of the juice, with $0.1 \mathrm{~N} \mathrm{NaOH}$ solution, previously standardized with potassium biftalate. The results were expressed as grams of citric acid per $100 \mathrm{~mL}$ of juice. The ratio was obtained by the soluble solids and titratable acidity contents. The loss of fresh mass was obtained by a gravimetric method, being the results expressed as a percentage, considering the difference between the initial mass of the fruit and that obtained in each sampling period.

The $\mathrm{CO}_{2}$ production by the fruits was determined after each exposure period to ethylene and on the other days of sampling. The determinations were made by gas chromatography on Gow Mac series 550, with thermal conductivity detector, equipped with an aluminum column filled with porapak $Q$. The working conditions were: entrainment gas flow (Helium) of $40 \mathrm{~mL} \mathrm{~min}^{-1} ; 150 \mathrm{~mA}$ of electric current; Column, detector and injector temperatures of 50,70 and $80^{\circ} \mathrm{C}$, respectively. The results were expressed in $\mathrm{mg} \mathrm{CO} \mathrm{kg}^{-1} \mathrm{~h}^{-1}$.

The solutes leakage was performed according to the methodology described by
Serek et al. (1995), with modifications. Nine 10 $\mathrm{mm}$ diameter discs were removed from the fruit peel per experimental unit. The disks were washed in distilled water and the surface dried with absorbent paper. Afterwards, they were rested for $2 \mathrm{~h}$ in test tubes containing $20 \mathrm{~mL}$ of distilled water under ambient conditions. After resting, the electrical conductivity of the water was measured. Subsequently, the test tubes with the peel disc samples were autoclaved $\left(121^{\circ} \mathrm{C}\right.$ at $1.5 \mathrm{~atm}$ ) for $30 \mathrm{~min}$ and then a second electrical conductivity measurement was performed. The results were expressed as the ratio between the values obtained in the first and second measurements, multiplied by 100 .

In the statistical analysis for the dose 'zero', no change was observed for the exposure times, being applied a simple regression analysis. For data of the doses of 5, 10, 20 and $40 \mathrm{\mu L} \mathrm{L}^{-1}$ of ethylene, times of exposure to ethylene were fixed, verifying the variations of the effects of the doses (D) and times after ethylene exposure (T) on each of the studied variables. For these data, the response surface technique was used. The choice of models was based on the significance of the regression coefficients by the 't' test at $5 \%$ probability, in the determination coefficient and in the model potential to explain the biological phenomenon. For the variable respiration rate, the descriptive statistics were used. For the variables color difference, Hue angle, chlorophyll and total carotenoid contents of the peel, the Dunnett test was also used to compare fresh fruits with those sampled after each time of ethylene exposure.

\section{Results and Discussion}

Fruit characteristics immediately after ethylene exposure

For the color difference $(C D)$, values for control fruits (freshly harvested) and treated fruits was observed at all exposure times (Table 1). The fruit exposure during $96 \mathrm{~h}$ was more efficient in changing the values of $C D$, Hue angle and total chlorophyll content of the peel, regardless the applied ethylene dose. The effects of the 24 and $48 \mathrm{~h}$ exposure times on these variables were similar, but different from those observed in $96 \mathrm{~h}$. Thus, exposure times of less than $96 \mathrm{~h}$ may present 
low efficiency in the promotion of the ethylene diffusion into the fruit, compromising its action on the degreening of the 'Ponkan' fruits peel. For the Hue angle, only fruits exposed to ethylene during $96 \mathrm{~h}$ differed from control fruits, regardless the dose used (Table 1).

The total chlorophyll content in the skin of fruits exposed to ethylene during 48 and $96 \mathrm{~h}$ differed from the control fruits, except for $48 \mathrm{~h}$ of exposure using the $10 \mu \mathrm{L} \mathrm{L}^{-1}$ dose. The same did not occur with fruits exposed to ethylene during $24 \mathrm{~h}$ (Table 1). Thus, the insufficiency of the 24hour time is assumed to allow the action of ethylene in the chlorophyll degradation process of the peel.

Regarding the total carotenoid content, no significant change in the contents was observed as a function of the exposure time, except for $96 \mathrm{~h}$ of exposure to $40 \mathrm{\mu L} \mathrm{L}^{-1}$ of ethylene, different from the control (Table 1). This suggests that during the phase in which the fruits were exposed to ethylene, the change in the color of the peel occurred only due to chlorophyll degradation, followed by the development of pre-synthesized carotenoid pigments.

Table 1. Mean values for color difference (CD), Hue angle, total chlorophyll (TCL, $\mu \mathrm{g} \mathrm{cm}^{-2}$ ) and total carotenoids (TC, $\mu \mathrm{g} \mathrm{cm}^{-2}$ ) of 'Poncã' tangerine fruits immediately after harvest (control) and after each time of exposure to ethylene doses.

\begin{tabular}{ccccc}
\hline Treatments (D/T) $^{1}$ & $\mathrm{CD}$ & Hue angle & $\mathrm{TCL}$ & $\mathrm{TC}$ \\
\hline Control $^{2}$ & 0.00 & 119.03 & 25.22 & 4.6 \\
\hline $5 / 24$ & $1.64^{*} \mathrm{~b}$ & $118.11 \mathrm{a}$ & $21.38 \mathrm{a}$ & $5.9 \mathrm{a}$ \\
$5 / 48$ & $5.50^{*} \mathrm{~b}$ & $113.42 \mathrm{~b}$ & $17.40^{*} \mathrm{a}$ & $5.2 \mathrm{a}$ \\
$5 / 96$ & $26.24^{*} \mathrm{a}$ & $94.45^{*} \mathrm{c}$ & $6.46^{*} \mathrm{~b}$ & $6.3 \mathrm{a}$ \\
\hline $10 / 24$ & $2.70^{*} \mathrm{~b}$ & $119.95 \mathrm{a}$ & $23.30 \mathrm{a}$ & $5.1 \mathrm{a}$ \\
$10 / 48$ & $5.07^{*} \mathrm{~b}$ & $115.34 \mathrm{a}$ & $18.95 \mathrm{a}$ & $5.2 \mathrm{a}$ \\
$10 / 96$ & $23.32^{*} \mathrm{a}$ & $97.35^{*} \mathrm{~b}$ & $6.77^{*} \mathrm{~b}$ & $5.8 \mathrm{a}$ \\
\hline $20 / 24$ & $3.33^{*} \mathrm{~b}$ & $118.63 \mathrm{a}$ & $24.12 \mathrm{a}$ & $6.3 \mathrm{a}$ \\
$20 / 48$ & $4.72^{*} \mathrm{~b}$ & $115.55 \mathrm{a}$ & $16.79^{*} \mathrm{~b}$ & $4.9 \mathrm{~b}$ \\
$20 / 96$ & $22.62^{*} \mathrm{a}$ & $94.72^{*} \mathrm{~b}$ & $5.76^{*} \mathrm{c}$ & $5.4 \mathrm{ab}$ \\
\hline $40 / 24$ & $3.31^{*} \mathrm{~b}$ & $117.34 \mathrm{a}$ & $21.33 \mathrm{a}$ & $5.6 \mathrm{a}$ \\
$40 / 48$ & $8.11^{*} \mathrm{~b}$ & $112.49 \mathrm{a}$ & $14.47^{*} \mathrm{ab}$ & $5.1 \mathrm{a}$ \\
$40 / 96$ & $17.20^{*} \mathrm{a}$ & $98.15^{*} \mathrm{~b}$ & $8.12^{*} \mathrm{~b}$ & $6.4^{*} \mathrm{a}$ \\
\hline
\end{tabular}

Means followed by "“" in columns are different from control according to Dunnett's test at $5 \%$ of probability; 'D: ethylene dose, $\mu \mathrm{LL}-1$; T: exposure time, hours; and ${ }^{2}$ Means of recently harvest fruits, with green peel. Means followed by the same letter for each ethylene dose in columns are not different according to Tukey's test at $5 \%$ of probability.

Regardless the dose and time of ethylene exposure, no differences was observed in soluble solids content, titratable acidity and (SS/TA) ratio in the flesh of fresh fruits, and no difference was also observed for the exposure times, within each dose (Table 2). Other authors did not observed changes in these variables in ethylene doses varying from 3 to $12 \mu \mathrm{L} \mathrm{L}^{-1}$ for the degreening of other citrus species, such as 'Siciliano' lemon, 'Satsuma' mandarin, 'Navel' orange and 'Star Ruby' grapefruit (Mendonça et al., 2003; Tietel et al., 2010; Mayuoni et al., 2011).

However, the leakage of cellular electrolytes within fruits treated with each dose differed from that observed in the newly harvested fruits. The higher percentages of cell electrolyte leakage may be a consequence of the longer exposure times of the fruits to the ethylene doses, since, with the exception of the fruits exposed to $5 \mu \mathrm{L} \mathrm{L}^{-1}$ of ethylene, the others showed higher values of electrolyte leakage from peel when exposed 48 and $96 \mathrm{~h}$ to the gas. With higher disarrangement of the membranes structure, due to the higher ethylene amount inside the fruits, a higher electrolytes leakage was observed. It should be noticed that, although the highest value of electrolyte leakage was observed in fruits exposed to $10 \mu \mathrm{L} \mathrm{L}^{-1}$ of ethylene (Table 2), no spots on the peel was observed and some fruits submitted to highest doses of ethylene presented brown spots on the peel. The spots began to appear $72 \mathrm{~h}$ after ethylene treatment in fruits exposed to $40 \mu \mathrm{L} \mathrm{L}-1$ for $96 \mathrm{~h}$. After $96 \mathrm{~h}$, end of the treatment, fruits exposed to the dose of $20 \mu \mathrm{L} \mathrm{L}^{-1}$ of ethylene for $96 \mathrm{~h}$ also presented expressively toxicity symptoms, compromising almost the entire peel surface. 
Fruit characteristics on the days after the end of the ethylene exposure

On the peel, the observed electrolytes leakage in control fruits was similar to the leakage observed in fruits exposed to ethylene for $24 \mathrm{~h}$, despite the dose, presenting an increase behavior in the time $\left(\hat{Y}_{\text {control }}=26.425+0.1634 * \mathrm{~T}\right.$ $\left.r^{2}=0.8486 ; \hat{Y}_{24 \text { hours }}=26.04+0.1342 * * T \quad r^{2}=0.4875\right)$. Fruits exposed for 48 and $96 \mathrm{~h}$ did not presented differences in electrolytes leakage after the end of the ethylene treatment. This is due to the fact that, at the end of the treatment, fruits already presented electrolytes leakage of 32.3 and $30.0 \%$, for 48 and $96 \mathrm{~h}$ of ethylene exposure, respectively (Table 2 ). The increase in electrolyte leakage indicates loss of selective permeability of cell membranes, due to the natural process of senescence. The changes are due to decreased lipid fluidity and structural alteration and loss of membrane proteins during senescence (Serek et al., 1995).

Table 2. Mean values for soluble solids (SS), titrable acidity (TA), (SS/AT) ratio and percentage of electrolytes leakage of the peel (EL) of recently harvested (control) 'Ponkan' tangerine fruits and after each time of ethylene exposure.

\begin{tabular}{|c|c|c|c|c|}
\hline Treatments (D/T)' & SS & TA & Ratio & $\mathrm{EL}$ \\
\hline Control $^{2}$ & 9.0 & 0.93 & 9.7 & 21.0 \\
\hline $5 / 24$ & $9.0 a$ & $0.92 a$ & $9.8 a$ & $24.0 * a$ \\
\hline $5 / 48$ & $8.8 a$ & $0.97 a$ & $9.1 \mathrm{a}$ & $31.2^{*} \mathrm{a}$ \\
\hline $5 / 96$ & $8.8 \mathrm{a}$ & $0.93 a$ & $9.5 a$ & $30.2^{*} a$ \\
\hline $10 / 24$ & $9.1 \mathrm{a}$ & $0.99 a$ & $9.3 a$ & $24.3^{*} \mathrm{~b}$ \\
\hline $10 / 48$ & $9.0 \mathrm{a}$ & $0.90 \mathrm{a}$ & $10.0 \mathrm{a}$ & $35.8^{*} a$ \\
\hline $10 / 96$ & $9.4 a$ & $0.99 a$ & $9.5 \mathrm{a}$ & $29.2 * a b$ \\
\hline $20 / 24$ & $9.1 \mathrm{a}$ & $0.90 a$ & $10.1 \mathrm{a}$ & $23.5^{*} \mathrm{~b}$ \\
\hline $20 / 48$ & $9.1 \mathrm{a}$ & $0.96 a$ & $9.5 \mathrm{a}$ & $31.8^{*} \mathrm{a}$ \\
\hline $20 / 96$ & $9.0 \mathrm{a}$ & $0.91 \mathrm{a}$ & $9.9 \mathrm{a}$ & $31.0 * a$ \\
\hline $40 / 24$ & $9.0 \mathrm{a}$ & $0.90 a$ & $10.0 \mathrm{a}$ & $23.6 * b$ \\
\hline $40 / 48$ & $8.8 a$ & $0.88 a$ & $10.0 \mathrm{a}$ & $30.3^{*} \mathrm{a}$ \\
\hline $40 / 96$ & $8.9 \mathrm{a}$ & $0.94 a$ & $9.8 \mathrm{a}$ & $29.7 * a$ \\
\hline
\end{tabular}

The difference in the peel color of control fruits followed a sigmoidal behavior, with initial values around 3, a slight evolution in the first 24 $h$, followed by a significant increase between 24 and $72 \mathrm{~h}$ and a tendency of stabilization between 72 and 96 h, to around 20 (Figure 1A). According to Mazzuz (1996), the most suitable temperature for degreening is 18 to $25^{\circ} \mathrm{C}$. As the fruits of all treatments were maintained under these conditions, even those not treated with ethylene presented discrete chlorophyll degradation, which was sufficient to increase the color differences between times of ethylene exposure.

Fruits exposed to ethylene for $24 \mathrm{~h}$ (Figure 1B) presented a linear evolution for the peel color change due to an increase in the time after ethylene treatment and an increase of the applied doses, being the magnitude of the values similar to that verified In control fruits (Figure 1B).

Fruits treated for $48 \mathrm{~h}$ (Figure 1C), although presented higher values for ED in relation to control fruits and those exposed for $24 \mathrm{~h}$, did not presented differences in the color. At $96 \mathrm{~h}$ of exposure, the fruits presented, immediately after ethylene treatment, initial SD values higher than those observed for the other fruits (Table 1), with an average value between the doses of 22.3.

The change in the peel color of the fruits exposed to ethylene for $96 \mathrm{~h}$, initiated during treatment and was completed after the treatment, when fruits presented a maximum value of 35.2 after 88.2 h of the end of the treatment with ethylene, regardless the gas concentration (Figure 1D). Therefore, fruits exposed to ethylene for $96 \mathrm{~h}$ showed increasing values of $C D$ for a longer time than those exposed for $48 \mathrm{~h}$, with stable values at $79.4 \mathrm{~h}$ after ethylene exposure. It is likely that longer exposure time, higher the ethylene effect on fruits treated for $96 \mathrm{~h}$, which was confirmed by the visual observation of the fruits over the time in which they were evaluated. This indicates an importance of higher than 48 $\mathrm{h}$ of exposure, so that the ethylene is diffused 

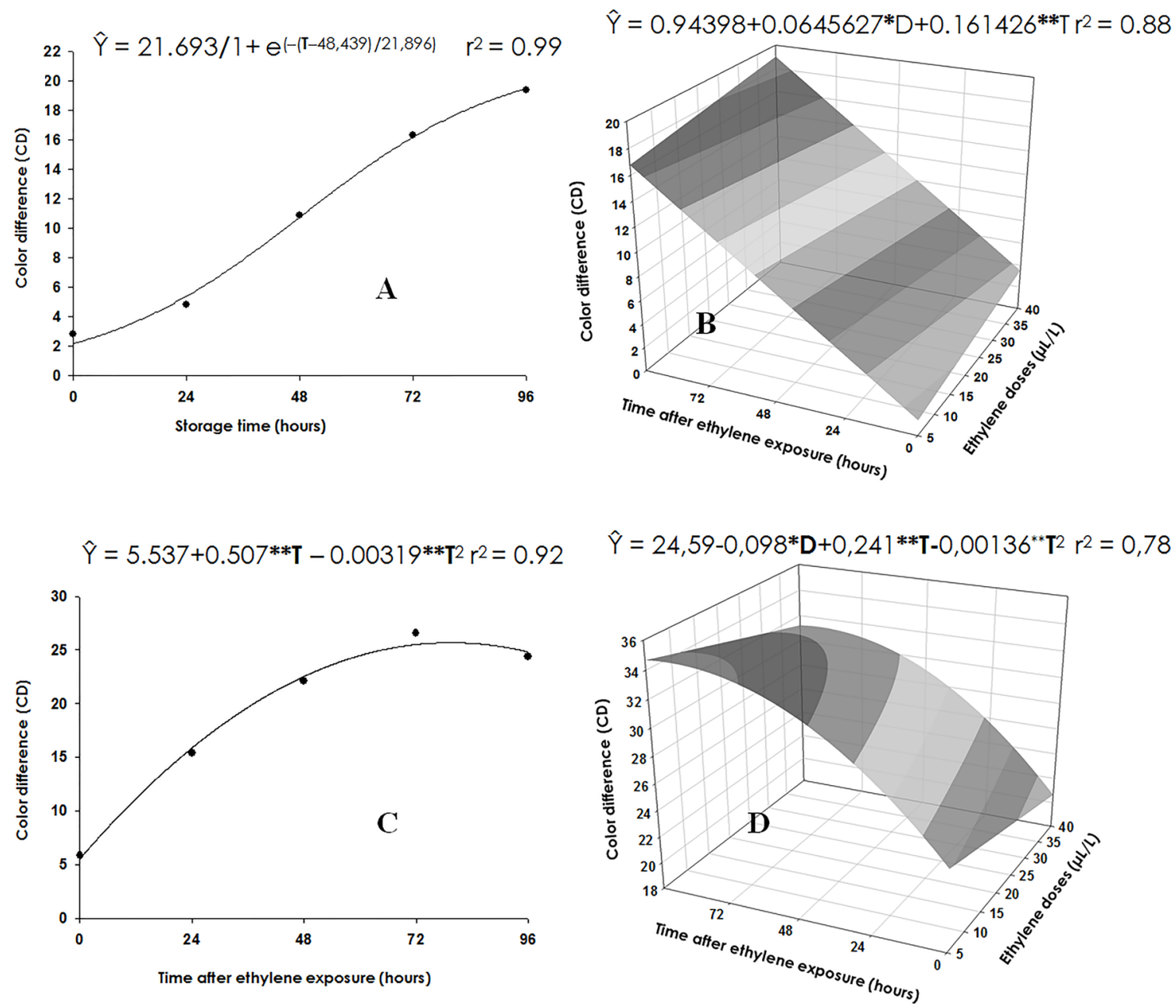

Figure 1. Estimation of the color difference of 'Ponkan tangerine fruits compared to fresh fruits, as a function of the doses (D) and the time after ethylene exposure (T). A - control fruits, not treated; B - fruits exposed to ethylene for $24 \mathrm{~h}$; C - fruits exposed to ethylene for $48 \mathrm{~h}$; and D - fruits exposed to ethylene for $96 \mathrm{~h}$

into the fruits and triggers the loss of the green coloration of the peel.

There was no dose effect on the Hue angle, regardless of the exposure time to ethylene. For all conditions, only the effect attributed to the time after ethylene exposure was observed (Figure 2). For fruits not treated with ethylene (Figure 2A), the Hue angle presented a linear behavior as a function of the storage times, with tendency to reduce the values over time, as observed by Zhou et al. (2010).

The hue angle values of control fruits and for fruits exposed to ethylene for $24 \mathrm{~h}$ were similar during the 96 hours after the end of the ethylene exposure (Figure 2AB). The value ranges and the final color of the fruits from both conditions were similar, indicating that $24 \mathrm{~h}$ of ethylene exposure was not sufficient to a complete degreening, as observed by Mendonça et al. (2003) in lemon, with differences in the Hue angle value for control and the minimum time of $48 \mathrm{~h}$ of exposure, using the doses 3,6 an $12 \mu \mathrm{L} \mathrm{L}^{-1}$.

Fruits exposed to ethylene for $48 \mathrm{~h}$ (Figure 2C) presented a more marked peel color change over the $96 \mathrm{~h}$ after treatment. Only fruits exposed to ethylene for $96 \mathrm{~h}$ presented Hue angle values lower than $90^{\circ}$, indicating a tendency of orange color, obtained $24 \mathrm{~h}$ after the treatment with ethylene, regardless the applied dose (Figure 2D). For the unripe fruits, which matured in the plant, the Hue angle was $88.3^{\circ}$, with not homogenous peel color, with strong traces of green color, 77 days after harvest of the other fruits to set up the experiment.

Although fruits exposed to ethylene for $96 \mathrm{~h}$ reached a higher degree of degreening 

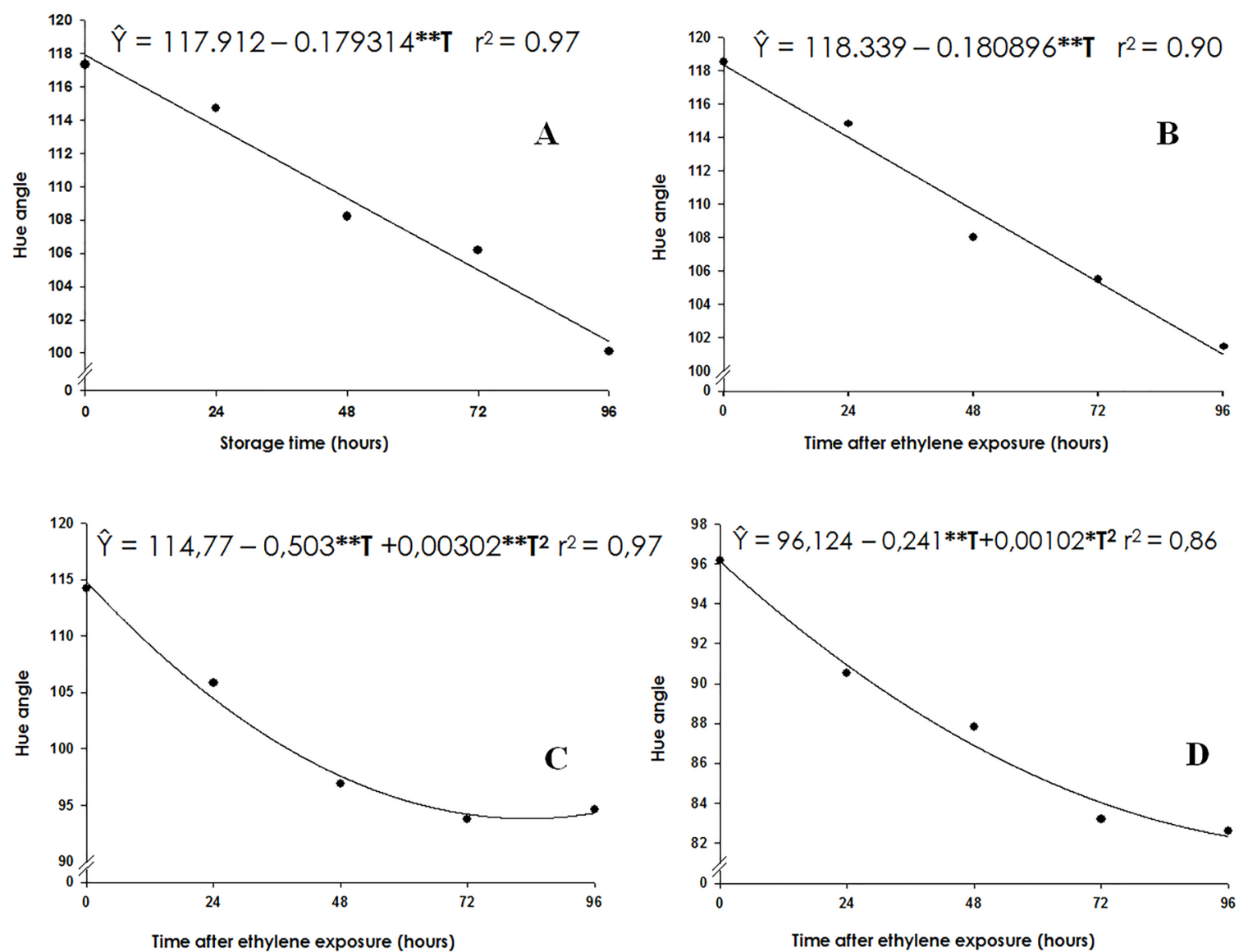

Figure 2. Estimation of the Hue angle (h) of 'Ponkan' tangerines, as a function of the time after the end of ethylene exposure (T). A - untreated control fruits; B - fruits exposed to ethylene for 24 hours; C - fruits exposed to ethylene for 48 hours; D - fruits exposed to ethylene for 96 hours.

than the other treatments, the loss of the green color of the fruit peel is closely related to time (treatment phase + after treatment phase), more than to the time of exposure of the fruits to ethylene. With a total of $96 \mathrm{~h}$ (48 $\mathrm{h}$ of exposure $+48 \mathrm{~h}$ after exposure), fruits presented Hue angle values similar to those observed in the fruits exposed to ethylene for $96 \mathrm{~h}$ right after gas exposure (Figure 2CD). According to this and to the fact that the fruits treated for $96 \mathrm{~h}$ were more yellow, it is possible that the greater efficiency of this exposure time is related to the greater diffusion of the ethylene into the fruits, resulting in a greater availability for the promotion of a most complete peel degreening.

At $96 \mathrm{~h}$ after the end of ethylene exposure, fruits treated for 48 and $96 \mathrm{~h}$ presented lower total chlorophyll content than control fruits (Figure 3). In turn, those exposed for $24 \mathrm{~h}$ showed both initial and final levels similar to control fruits, confirming the insufficiency of this exposure time. In the fruits exposed to ethylene for $48 \mathrm{~h}$ linear behavior as a function of time after the end of ethylene exposure. As soon as they were removed from the treatment boxes, the fruits had a mean content of total chlorophyll in the peel of $16.9 \mathrm{\mu g} \mathrm{cm}^{2}$ for the doses, and a marked drop was observed up to $36.6 \mathrm{~h}$ after treatment, reaching a minimum value of $6.9 \mu \mathrm{g} \mathrm{cm}^{-2}$, with stabilization until the end of the evaluation time.

The fruits exposed to ethylene during $96 \mathrm{~h}$, and after the treatment already presented total chlorophyll contents similar to the minimum presented by the fruits exposed during $48 \mathrm{~h}$, reached only $36.6 \mathrm{~h}$ after the end of the exposure (Figure 3CD). In fruits treated for $96 \mathrm{~h}$, the total chlorophyll content was linearly reduced throughout the $96 \mathrm{~h}$ after treatment. The degradation achieved the maximum at $96 \mathrm{~h}$ after the end of treatment with ethylene, reaching an average content of $2.8 \mu \mathrm{g} \mathrm{cm}^{-2}$. Thus, the $96 \mathrm{~h}$ period of exposure to ethylene plus a further 48 to $72 \mathrm{~h}$ is the best option for obtaining a peel color favorable to commercialization. 

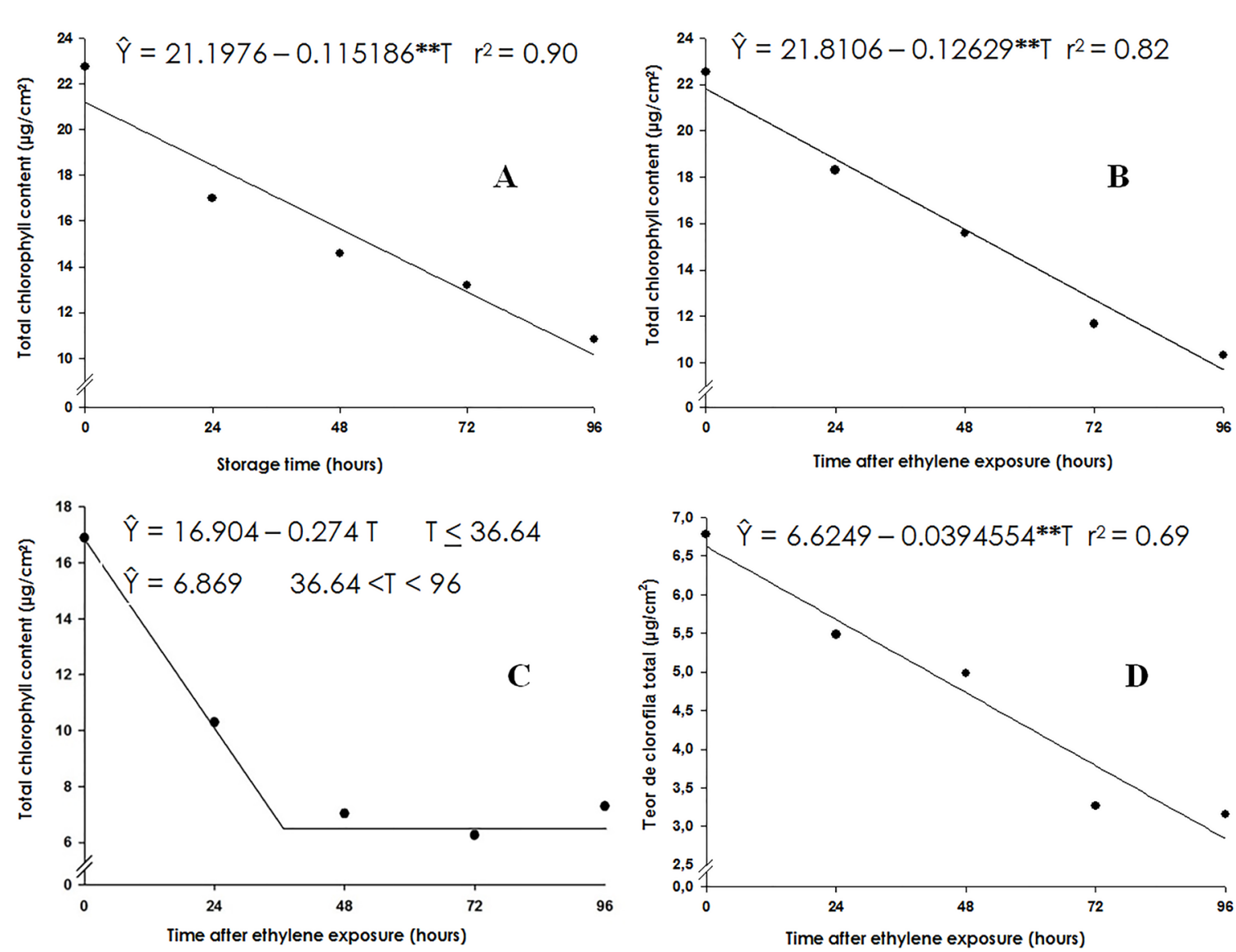

Figure 3. Estimation of the total chlorophyll content of the 'Ponkan' tangerine fruit peel, as a function of the time after the end of exposure to ethylene (T). A - control fruits, not treated; B - fruits exposed to ethylene for 24 h; C - fruits exposed to ethylene for $48 \mathrm{~h}$; and D - fruits exposed to ethylene for $96 \mathrm{~h}$.

The carotenoids synthesis in the fruit peel, despite the treatment condition, presented a slight increase after the treatment period, varying from 12 to $40 \%$ for the fruits exposed to ethylene for 24 and 96 h, respectively (Figure 4). Rodrigo \& Zacarias (2007) studying oranges (Citrus sinensis L. Osbeck) and Zhou et al. (2010) studying 'Ponkan', observed an increase of $20 \%$ and $43 \%$ in the total carotenoid content in fruits treated with $10 \mu \mathrm{L} \mathrm{L}^{-1}$ of ethylene and stored at $20^{\circ} \mathrm{C}$ for 7 days and at $10^{\circ} \mathrm{C}$ for 35 days, respectively.

It should be noticed that the results obtained with artificial degreening, in postharvest, are compromised with earlier harvests. Thus, as the fruits were harvested with the fully green peel, with no indication that natural greening had already been initiated, ethylene acted markedly, stimulating the activity of chlorophyllase as well as the 'de novo' synthesis (Azuma et al., 1999), contributing to the degreening, whose most significant cause was the degradation of chlorophyll, however, with little expression of the synthesis of new carotenoid pigments in the fruit peel.

The soluble solids, titratable acidity and the ratio between them (ratio) did not presented significant changes over time, as a function of the treatments to which the fruits were submitted, corroborating with Mendonça et al. (2003).

The accumulated weight loss at the end llast day of evaluation) of the $96 \mathrm{~h}$ was only $0.9 \%$, referring to the fruits that stayed longer ( $96 \mathrm{~h}$ ) exposed to the higher ethylene doses, and no dose effect was observed on the loss of fresh fruit mass, corroborating with Mendonça et al. (2003) who also did not observed an effect of the ethylene doses on the loss of fresh mass of 'Siciliano' lemons. The loss of low expressive fresh mass may be due to the high relative humidity in the air inside the chambers where the fruits were kept during and after the treatments with ethylene. The small percentage of fresh mass loss, regardless the time of exposure of the fruits to ethylene, ensures the possibility of recommending the longer exposure 

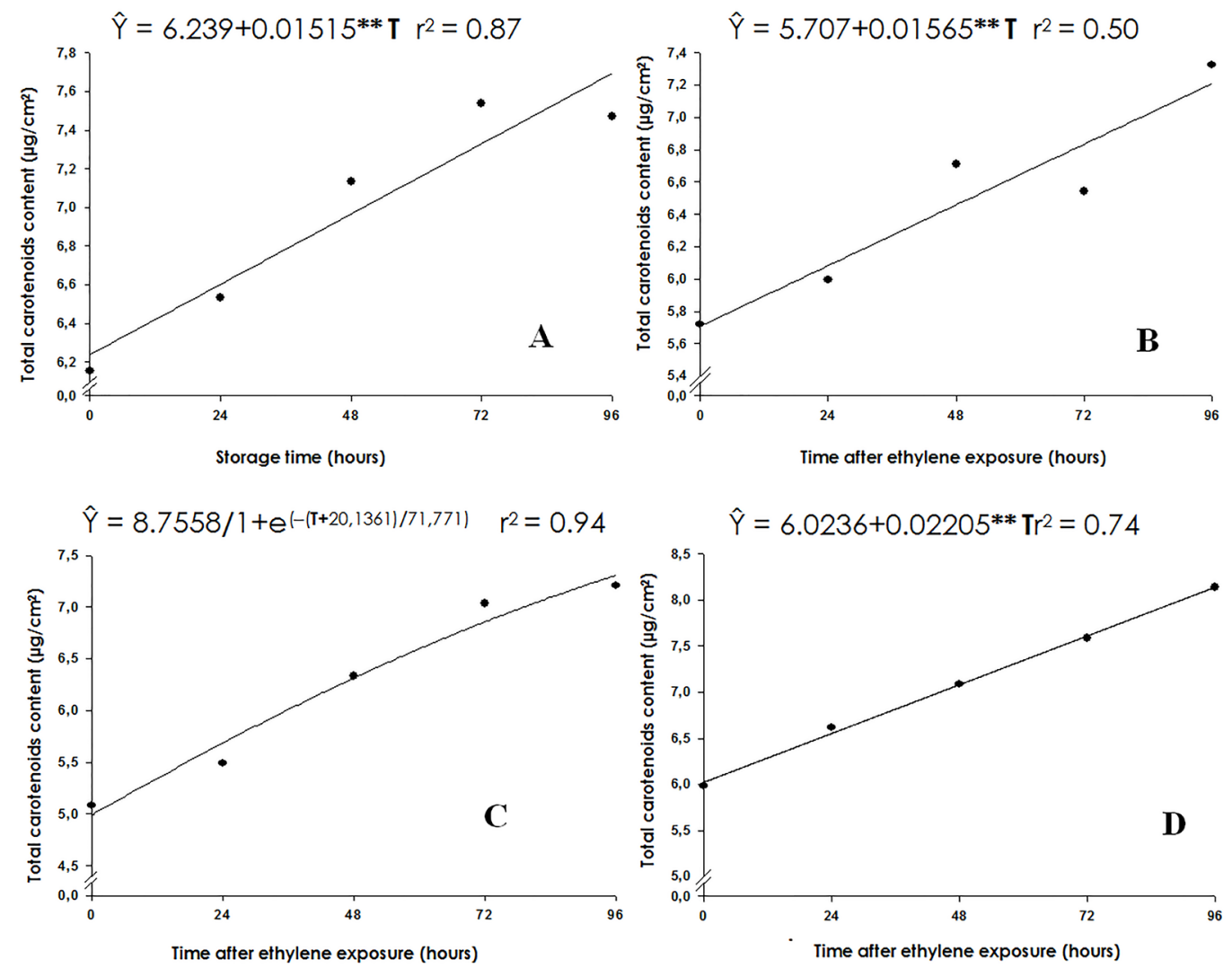

Figure 4. Estimation of total carotenoid content of 'Ponkan' tangerine fruit peel, as a function of time after the end of ethylene exposure (T). A - control fruits, not treated; B - fruits exposed to ethylene for $24 \mathrm{~h}$; C - fruits exposed to ethylene for $48 \mathrm{~h}$; and D - fruits exposed to ethylene for $96 \mathrm{~h}$.

times, since, as observed, the fruits did not show, at any moment, signs of wilting or wrinkling on the peel.

Immediately after the end of the ethylene exposure period, the fruits presented the highest respiratory rates during the evaluated period, regardless the applied dose. The control fruits (not submitted to ethylene) presented the same behavior (Figure 5). This situation occurred because the fruits of all treatments (doses and control) were stored in airtight boxes, including control fruits, during the ethylene exposure phase. In this condition, the concentration of $\mathrm{CO}_{2}$ inside the chamber increased, inhibiting the gas diffusion from inside to outside the fruit tissue.

In general, after $24 \mathrm{~h}$ of the end of the treatment, a decrease in the respiratory rate of fruits was observed, regardless the exposure time and the applied dose (Figure 5), as expected from a non-climacteric fruit. This abrupt reduction in respiration after the end of exposure to ethylene may have been a consequence of the diffusion of both ethylene and $\mathrm{CO}_{2}$ from the interior of the fruits into the atmosphere outside the tissues.
Without the interference of exogenous ethylene on fruit metabolism and without the restriction of $\mathrm{CO}_{2}$ diffusion from the tissues to the external environment, the respiratory rate fell and tended to stabilize at the end of the evaluation period (Figure 5).

There was a slight decrease in the respiration rate in fruits treated with ethylene for $96 \mathrm{~h}$ (Figure 5C), probably due to the longer time of exposure, resulting in a higher gas concentration inside the tissues and more diffusion from the interior of the fruit to the external atmosphere. However, regardless the dose, the fruits showed similar respiratory behavior, indicating that there was no effect of the dose on their respiratory pattern.

\section{Conclusions}

Exposure to $5 \mu \mathrm{L} \mathrm{L}^{-1}$ of ethylene for $96 \mathrm{~h}$ and an exposure for 48 to $72 \mathrm{~h}$ after treatment (during storage) is the combination that provides the best results on fruit peel degreening, which shows no evidence of loss of marketing quality at the end of the experiment.

The fruits were yellowish using the best 
A

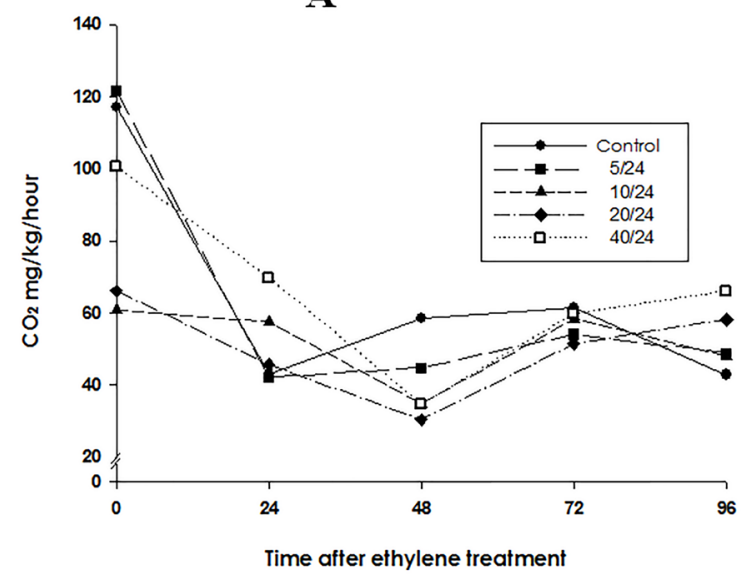

Time after ethylene treatment

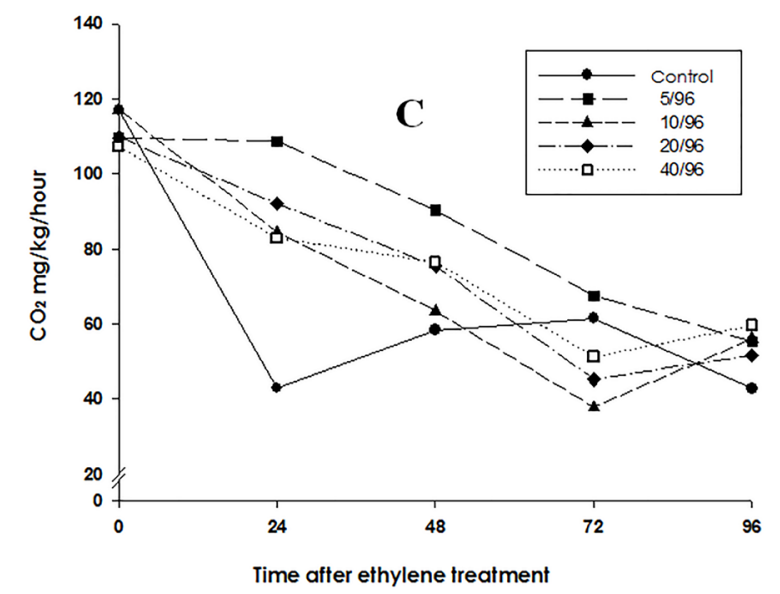

B

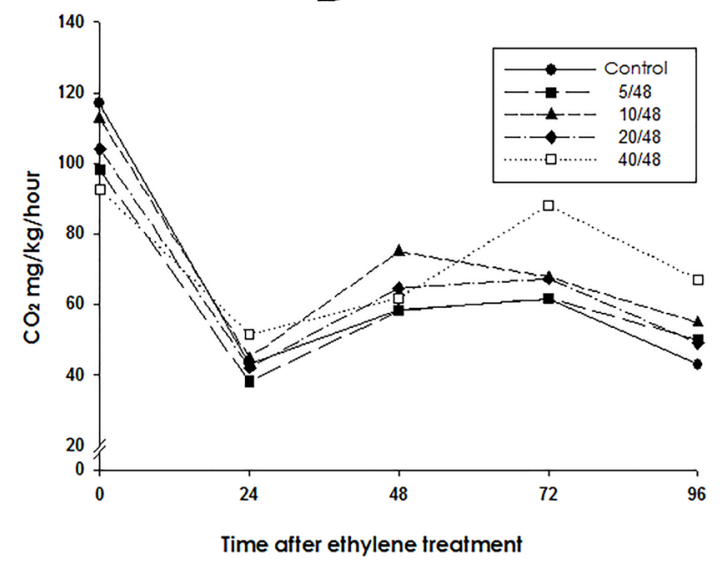

Figure 5. $\mathrm{CO}_{2}$ production from 'Ponkan' tangerines submitted to ethylene doses of $0,5,10,20$ and $40 \mu \mathrm{L} \mathrm{L}$ '- in the $96 \mathrm{~h}$ after the end of the treatments. A - fruits exposed for $24 \mathrm{~h}$; B - fruits exposed for $48 \mathrm{~h}$; and C - fruits exposed for $96 \mathrm{~h}$.

experimental combination, but without the characteristic orange color of the species, which means that the degreening is, mainly, a direct consequence of the peel chlorophyll degradation.

\section{References}

Azuma, R., Kurata, H., Masaru, A., Shimokawa, K. 1999. Degreening of Citrus unshiu fruits via ethylene - induced solube chlorophyllase. Journal of the Japanese Society for Horticultural Science 68: 558-562.

Jomori, M.L.L., Sasaki, F.F. C., Berno, N.D., Gimenes, L.C., Kluge, R.A. 2014. Desverdecimento e armazenamento refrigerado de tangor 'Murcott' em função de concentração e tempo de exposição ao etileno. Semina: Ciências Agrárias 35: 825-834.

Lichtenthaler, H.K. 1987. Chlorophylls and carotenoids: pigments of photosynthetic biomembranes. Methods in Enzymology 48: 350 382.

Mayuoni, L., Tietel, Z., Patil, B.S., Porat, R. 2011. Does ethylene degreening affect internal quality of citrus fruit? Postharvest Biology and Technology 62: $50-58$.

Matsumoto, H., Ikoma, Y., Kato, M., Nakajima, N., Hasegawa, Y. 2009. Effect of postharvest temperature and Ethylene on carotenoid accumulation in the flavedo and juice sacs of satsuma mandarin (Citrus unshiu Marc.) fruit. Journal of Agricultural and Food Chemistry 57: 4724-4732.

Mazzuz, C.F. 1996. Calidad de frutos citricos: manual para sugestion desde la recoleccion hasta la expedicion. Edicones de Horticultura, Barcelona, Espanha. 317 p.

Mendonça, K., Jacomino, A.P., Melhem, T.X., Kluge, R.A. 2003. Concentração de etileno e tempo de exposição para desverdecimento de limão 'Siciliano'. Brazilian Journal of Food Technology 6: 179-183.

Mendoza, F.; Dejmek, P., Aguilera, J.M. 2006. Calibrated colour measurements of agricultural foods using image analysis. Postharvest Biologyand Technology 41: 285-295.

Moscoso-Ramírez, P.A., Palou, L. 2014. Effect of ethylene degreening on the development of 
postharvest penicillium molds and fruit quality of early season citrus fruit. Postharvest Biology and Technology 91: 1-8.

Rodrigo, M.J., Zacarias, L. 2007. Effect of postharvest ethylene treatment on carotenoide accumulation and the expression of carotenoid biosynthetic genes in the flavedo of orange (Citrus sinensis L. Osbeck) fruit. Postharvest Biology and Technology 43: 14-22.

Sdiri, S., Navarro, P., Monterde, A., Benabda, J., Salvador, A. 2012. New degreening treatments to improve the quality of citrus fruit combining different periods with and without ethylene exposure. Postharvest Biology and Technology 63: 25-32.

Serek, M., Tamari, G., Sisler, E.C., Borochov, A. 1995. Inhibition of ethylene-induced cellular senescence symptoms by 1-methylcyclopropene, a new inhibitor of ethylene action. Physiologia Plantarum 94: 229-232.

Tietel, Z., Weiss, B., Lewinsohn, E., Fallik, E., Porat, R. 2010. Improving taste and peel color of earlyseason Satsuma mandarins by combining hightemperature conditioning and degreening treatments. Postharvest Biology and Technology 57: 1-5.

Spósito, M.B., Julianetti, A., Barbasso, D.V. 2006. Determinação do índice de cor mínimo necessário para a colheita de laranja doce valência a ser submetida ao processo de desverdecimento. Laranja 27: 373-379.

Vale, A.A.S., Santos, C.D., Abreu, C.M.P., Corrêa A.D., Santos, J.A. 2006. Alterações químicas, físicas e físico-químicas da tangerina ponkan (Citrus reticulata Blanco) durante 0 armazenamento refrigerado. Ciência e Agrotecnologia 30: 778786.

Zhou, J.Y., Sun, C. D., Zhang, L.L., Dai, X. Xu, C.J., Chen, K.S. 2010. Preferential accumulation of orange-colored carotenoids in Ponkan (Citrus reticulata) fruit peel following postharvest application of ethylene or ethephon. Scientia Horticulturae 126: 229-235. 